\title{
Creating a Culture of Activism in the Education Doctorate
}

\author{
Christine Lynn McClure \\ cmcclure@ncjfcj.org
}

\begin{abstract}
Attempting to combine activism and scholarship would seem natural because most academic research is born out of a deep-rooted desire to change, eradicate, or transform a societal issue. As such, translating research into practice by way of activism would seem conventional for most scholars, because it is "informed by both personal and political values and the need to engage our emotional responses to the world around us" (Derickson \& Routledge, 2015, p. 5). However, the elite, "ivory-tower" of the academy is not so accepting of scholar-activists. Perhaps it is because activism places higher education in the cross hairs of the criticisms, critiques, and call-outs that activism seeks to influence. Institutions of higher education have done a mediocre job at cultivating spaces for academics to freely engage in activism, as academics who desire to participate in activism face considerable and specific career-related risks (Flood et al., 2013). Loss of tenure, reduced opportunities for collaboration, decreased funding, isolation, and oftentimes physical threats are but a few strategies used against academics who openly participate in activism. While many activist movements have been birthed on college and university campuses, very few demonstrate a willingness to embrace the causes or individuals involved in these activist movements. As institutions of higher education try to strengthen both the policies and practices related to diversity, equity, and inclusion it is imperative that they also examine the oppressive structures, antiquated hiring practices, and exclusionary curriculum that inhibit the culture of activism from thriving. These three specific areas are the focus for this article.

KEYWORDS

activism, higher education, doctoral studies, diversity
\end{abstract}

\section{INTRODUCTION}

As scholars and practitioners, we have been trained in specific disciplines to follow a set of ethical guidelines while conducting and reporting on research. These standards are said to be based in moral principles that do not cause harm to the integrity of science and to human or animal life (Creswell, 2013). These standards are rooted in the principles of honesty, integrity and responsibility, however, promoting the participation in activism in higher education does not come without risk (Flood et al., 2013). Attempting to combine activism and scholarship seems to be a natural fit, because most academic research is born out of a deep-rooted desire to influence, revolutionize, or transform an issue or problem confronted by society. Therefore, translating research into activism would seem conventional for most scholars, because it is "informed by both personal and political values and the need to engage our emotional responses to the world around us" (Derickson \& Routledge, 2015, p. 5). However, the elite, "ivory-tower" of the academy is not so accepting of scholar-activists. Perhaps it is because activism places higher education in the cross hairs of the criticisms, critiques, and call-outs that activism seeks to influence. The purpose of this paper is to examine the areas in higher education that require additional strengthening to allow education doctorate programs to increase activism participation and awareness.

New articles in this journal are licensed under a Creative Commons Attribution 4.0 United States License.

\section{HISTORY OF THE DOCTORATE IN EDUCATION}

The first doctorate in education was awarded in 1921 at Harvard University, when Henry Holmes established the Harvard Graduate School of Education (Perry, 2015). Coursework lasted for five years, and was followed by the completion of a dissertation used to teach students how to conduct independent research. The overall goal of the program was to train and equip experienced educators to serve in high level leadership roles as practitioners (Cremin, 1978). After Harvard University began to offer the doctorate in education, many other institutions in the country began to follow suit and the education doctorate grew in popularity.

There has always been a misperception and debate about the $\mathrm{EdD}$ and the $\mathrm{PhD}$ in education. While they are similar, they do have their differences. The EdD is more of a practitioner's degree that prepares individuals for high-level leadership roles in various areas of education, while the $\mathrm{PhD}$ is more of a traditional doctorate that prepares individuals for a faculty career focused on research and teaching. The differences in degree and program requirements are oftentimes minimal, however, each schools' requirements are different. The doctorate in education has come under criticism for not being an authentic doctorate, and those who oppose the degree believe that it weakens the position of the doctorate (Nelson \&
This journal is supported by the Carnegie Project on the Education Doctorate: A Knowledge Forum on the EdD (CPED) cpedinitiative.org impactinged.pitt.edu Vol. 6 No. 1 (2021)
ISSN 2472-5889 (online) DOI 10.5195/ie.2021.128 
Coorough, 1994). The degree has oftentimes been referred to as "PhD-lite", and there were calls to eliminate the degree altogether from degree programs (Perry, 2015). Instead, as a way to increase credibility and to reorganize the degree requirements for the EdD, the Carnegie Project of the Education Doctorate (CPED) was established. The original project was funded in 2007 with a $\$ 700,000$ grant from the US Department of Education and started with 21 members. The goal of the project was to evaluate the EdD programs of the CPED member institutions to identify problems and weaknesses in their programs and to come together to redesign the programs in way that was more universal (Perry, 2015). Since 2007, CPED has evolved from a grant funded project, to a stand-alone 501 (C) 3 organization with over 86 members in the US, Canada, and New Zealand (Perry, 2015). Moreover, CPED has been responsible for an overhaul in how EdD programs are structured and delivered, which has helped to provide greater distinction between the $\mathrm{ED}$ and the $\mathrm{PhD}$ in education.

\section{ACTIVISM IN HIGHER EDUCATION}

According to Flood et al. (2013) "academics who seek to combine activism with work in the university can be subject to threats, abuse, silencing tactics, and peer pressure and scholarly expectations to shift away from activism" (p. 17). However, as scholars we have the responsibility to use our privileged positions, to "produce knowledge and to inform progressive change" (Flood, et al., p. 17). Knowledge production innately, produces change, which is a form of activism. Activism has many definitions, and depending on the circumstance can mean different things to different people. In general, activism is the use of "vigorous campaigning, with efforts to promote, disrupt or interrupt social, political, economic, and environmental climates within society" (Dictionary.com, 2019). Scholactivism is the point in which scholarship and activism intersect to create social change (Farnum, 2016). This idea is different from pursuit of the traditional academic, whereby the traditional academics' goal is to create new knowledge for dissemination to the public. Scholactivists desire not only create new knowledge but to work as practitioners of knowledge in the communities they seek to understand. The education doctorate is by definition a practitioner's degree. According to Perry (2015), individuals who possess doctorates in education "use practical research and applied theories as tools for change because they understand the importance of equity and social justice" (p. 59). Activism in higher education has become more pervasive in recent years, especially around issues of equity and social justice (Cole \& Heineckle, 2018). Our country's history is full of examples where college students were involved in activism, in particular, on college campuses. This college student participation has forced those in leadership roles in higher education leadership to develop protocols around how to manage and respond to protests and while also staying neutral on the issues. In addition, many faculty have come out in support of or in condemnation toward certain societal issues, which has further increased the need for institutional leadership to address the issue of activism in higher education.

\section{CHALLENGING THE CONSTRUCTS OF HIGHER EDUCATION}

In the colonial era when institutions of higher education were established, they were only accessible to White males from affluent families (Thelin, 2004). Women and members of minority groups were denied access to higher education, and other civil liberties, therefore, the culture of the academy is one that was built on a history of elitism, and discrimination. While institutions of higher education have become more diverse with individuals from underrepresented groups entering the academy in increasing numbers, "higher education still represents the complex relations between race, property, and oppression" (Patton, 2016, p. 320). As a result, the academy looks very different demographically, however, its espoused values, structure, and governance remain unchanged. One would argue that one of the reasons that the academy is so activism-adverse is because embracing activism would challenge the core values and beliefs of the academy. The system we call higher education was shaped by racism, sexism, and classism, which is still present today. To understand and effectuate change in higher education "requires acknowledging it's violent, imperialistic, oppressive past" (Patton, 2016 p. 317). Therefore, building a culture of activism in higher education requires an acknowledgement the acceptance of higher education's ugly past to begin to disrupt the normative oppressive structures that have served as the pillars of higher education thus far. While acknowledgement alone will not address the problem, it is a start to moving the academy away from its elitist culture toward one that truly embraces diversity and inclusion. In this paper I will discuss three distinct ways that higher education can promote and support participation in activism within higher education, in particular within its EdD programs.

\section{INCREASE EFFORTS TO RECRUIT MINORITY FACULTY}

According to the National Center for Education Statistics (NCES), university-level faculty in the United States in 2017 was comprised of $54 \%$ White males, $27 \%$ White females, $8 \%$ Asian/Pacific Islander males, $3 \%$ Asian/Pacific Islander females, with Black males, Black females, Hispanic males, and Hispanic females, each accounting for only $2 \%$ of all full-time professors (NCES, 2017). Although enrollment into graduate programs, such as doctorate programs has increased exponentially by minority groups, such as Black women, who have increased graduate school enrollment by over $400 \%$ since 1970 , they along with other minorities remain underrepresented as faculty in higher education (American Federation of Teachers; 2010, Flaherty, 2015; McClure, 2018). Minorities who are working in higher education are doing so at lower levels, as the majority of full professors are White. Leadership roles in higher education are no different, with roles such as college and university presidents, deans, chairs, and trustees being primarily occupied by White men (Patton, 2016). The lack of diversity in the faculty further perpetuates the culture of oppression and elitism in higher education which stifles potential growth and prevents higher education from maximizing its full potential.

The benefits of having a diverse faculty have been cited as "playing an integral role in advancing new knowledge and fostering pluralistic perspectives among students who will advance equity in a global society" (Zambraba et al., 2015 p. 2). Essentially, minority faculty are contributing to the cause of social justice through their teaching and mentoring students in the ways of equity and fairness. A study conducted by Umbach (2006) concluded that students benefited greatly by interacting and learning from faculty of color ( $p$. 336). Increasing the number of faculty of color, has been long requested by student activists, however, institutions cite a shortage 
of minority doctoral degree holders as the reason the number of faculty of color remains scant (Flaherty, 2015). However, the Survey for Earned Doctorates published by the National Science Foundation (NSF) reported that on average $40 \%$ of all minorities who earned doctorate degrees in 2018 planned to enter the academy after graduation (NCSES 2018). This raises a different question, if minorities holding doctorate degrees plan to enter the academy, why are they still so underrepresented? Perhaps, the question is better directed toward the institutions who would hire them. Increasing minority faculty presence, in and of itself is a way that institutions of higher education can support and ignite activism, by supporting a cause that has seemingly fallen on deaf ears.

\section{INCORPORATE ACTIVISM INTO THE CURRICULUM}

Graduate school curriculum, including at the doctoral level, has been criticized for being too White (Wall, 2013). Graduate level curriculum that lacks depth, diversity, and reinforces the hegemonic practices within higher education. Often time's students of color feel as though they are being placed in the margin, including where curriculum is concerned. In graduate education, and especially within doctoral programs, students of color are typically "the only one", and during classroom discussions, they either feel silenced or are placed in a position to speak for their entire race (hooks, 1994). This is oftentimes because people of color, their culture and history are excluded from the curriculum (Harris, 1993; Patton et al., 2015; Patton, 2016). Redesigning graduate school curriculum to incorporate a broader range of epistemologies, pedagogies, and literature has the potential to decrease the negative experiences people of color confront in graduate school, as well, a spark interest in new genres, areas of study, and increase awareness as it relates to the struggles people of color face in everyday life. Institutions of higher education can take an "intersectional approach to curriculum development and learning", as way to demonstrate a commitment to the pluralistic society which is the academy (Harris \& Linder, 2018, p. 155). This could help to foster a culture of activism within higher education, including in education doctorate programs.

\section{CHALLENGE INTERNAL POWER DYNAMICS}

Higher education by design is an elite institution that can only be accessed by individuals who can prove themselves worthy of admittance (Thelin, 2004). However, admittance is not equivalent to acceptance. While institutions of higher education have become more diverse over time, individuals from minority and underrepresented groups still have issues with finding acceptance within the walls of the ivory tower (McClure, 2018). Issues of structural racism, sexism, and classism, still plague institutions of higher learning today. Individuals who are members of minority groups often find themselves as "outsiders within" fighting to exist in an environment that does not openly accept or embrace them (Collins, 2000). Attempts at activism by scholars from minority, and underrepresented groups face the highest levels of risk when attempting to conduct research that influences societal change, or research that directly involves societal change (Flood, et al., 2013). The reprisals they face can be severe, and damage their careers irreparably, and they face direct attacks from their institutions who may perceive them as threats to existing culture (Flood et al., 2013). Threats to career advancement by denying them tenure is often the weapon of choice used to thwart their current activism actions, and hinder any potential future involvement in activism. Institutions of higher education need to do a better job at eliminating these threats and to support faculty who choose to participate in activism. This can be done by clearly defining what they value in terms of diversity and by incorporating perspectives that challenge the existing power structures of higher education. Confronting the issues of privilege held by certain groups within higher education instead of finding ways to silence those who speak out is one of the most important strategies for promoting a culture of activism in higher education.

\section{CONCLUSION}

Incorporating activism into education doctorate programs is a natural fit. The origins of the degree clearly demonstrate its purpose for roles of leadership, change, and innovation. However, institutions of higher education have to address the structural issues of oppression that continue to dominate its culture. Institutions of higher education are positioned as respected leaders within their communities, and therefore, are expected to develop solutions for the everyday issues of society. Undertaking these issues requires a diverse faculty that is prepared to educate, train, and mentor students, through the use of a curriculum that embraces everyone, and prepares the next generation of socially, and politically responsible leaders.

\section{REFERENCES}

American Federation of Teachers (2010). Promoting racial and ethnic diversity in the faculty: What higher education unions can do. https://www.aft.org/sites/default/fles/factuly diversity0310.pdf

Basu, K. (2012). The country's oldest Ed.D. program will close down. Inside Higher Ed.

Carnegie Project on the Education Doctorate. (n.d.) The Knowledge Forum on the EdD. https://www.cpedinitiative.org/.

Cole, R., \& Heineckle, W. (2018). Higher education after neoliberalism: Student activism as a guiding light. Policy Futers in Education, 18(1), 90116. https://doi.org/10.1177/1478210318767459.

Collins, P. (2000). Black feminist thought. NY Routledge.

Cremin, L. (1978). The education of the educating professions. Washington, DC: American Association of Colleges for Teacher Education.

Creswell, J. (2013). Qualitative inquiry and research design: Choosing among five approaches. Sage Publications, Inc.

Dictionary.com (2019). Retrieved from Dictionary.com Activism | Definition of Activism at Dictionary.com

Derickson, D., \& Routledge, P. (2015). Resourcing scholar-activism: Collaboration transformation, and the production of knowledge. The Professional Geographer, 67(1), 1-7.

Farnun, R. (2016). Scholactivism -a growing movement of scholar-activists. University World News.

https://www.universityworldnews.com/post.php?story=201605301426063 45.

Flaherty, C. (2015). Demanding 10 Percent, Inside Higher Ed. https://www.insidehighered.com/news/2015/11/30/student-activists-wantmore-black-faculty-members-how-realistic-are-some-their-goals.

Flaherty, C. (2016). More Faculty Diversity, Not on Tenure Track. https://www.insidehighered.com/news/2016/08/22/study-finds-gainsfaculty-diversity-not-tenure-track.

Flood, M., Martin, B., \& Dreher, T. (2013). Combining academia and activism. Australian Universities' Review, (55)1, 17-26.

Harris, C. I. (1993). Whiteness as property. Harvard Law Review, 106(8), 1709-1791.

Harris, J.C., Linder, C. (2018). The racialized experiences of students of color in higher education and student affairs graduate preparation programs. The Journal of College Student Development, 59(2), 141-158. 
hooks, b. (1994). Teaching to transgress: Education as the practice of freedom. Routledge.

McClure, C. (2018). Count-our-space: Examining the counterspaces of Black woman pursing a doctorate in education [Doctoral dissertation, University of Pittsburgh]. ProQuest Dissertation Thesis Global

National Center for Education Statistics. (2017). Race/ethnicity of college faculty: 2017. Washington, DC.

National Center for Science and Engineering Statistics, Survey of Earned Doctorates. (2018). Statistical profile of postgraduation plans of doctorate recipients, by ethnicity, race, and citizen status:2018. https://ncses.nsf.gov/pubs/nsf20301/fata-tables@group7

National Science Foundation, National Center for Science and Engineering Statistics. 2019. Doctorate Recipients from U.S. Universities: 2018. Special Report NSF 20-301. Alexandria, VA.

Nelson, J.K., Coorough, C. (1994). Content analysis of the PhD versus the EdD dissertation. Journal of Experimental Education, 62(2), 158-168.

Patton, L.D. (2016). Disrupting postsecondary prose: Toward a critical race theory of higher education. Urban Education, 51(3), 315-342.

Patton, L. D., Harper, S. R., \& Harris, J. C. (2015). Using critical race theory to (re)interpret widely studied topics related to students in US higher education. In A. M. Martinez Aleman, B. Pusser, \& E. M. Bensimon (Eds.), Critical approaches to the study of higher education (pp. 193-219). John Hopkins University Press.

Perry, J. (2012). What does history reveal about the education doctorate? Latta \& Wunder (Eds.). Placing practitioner knowledge at the center of teach education (pp.51-75). Information Age Publishing.

Perry, J. (2015) The Carnegie Project on the Education Doctorate, Change: The Magazine of Higher Learning, 47(3), 56-

61, https://doi.org/10.1080/00091383.2015.1040712

Perry, J. (2015). The Carnegie project on the education doctorate. Change: The Magazine of Higher Education, 47 (3), 56-61.

Scott, D. (2016). Ph.D. vs. Ed.D.: Which terminal degree is right for you? Inside Higher Ed. http://www.insidehighered.com/blogs/gradhacker/phdvs-edd

Thelin, J. (2004). A history of American higher education. The Johns Hopkins University Press.

Umbach, P. (2006). The contribution of faculty of color to undergraduate education. Research in Higher Education, 47(3), 317-345.

Wall, M.L. (2013). Using balanced learning course design to reduce resistance to diversity curricula. Enhancing Learning in the Social Sciences, 5(2), 45-54.

Zambrana, R.E., Ray, R., Castro, C., Cohen, B., \& Eliason, J. (2015). Don't leave us behind: The importance of mentoring for underrepresented minority faculty. American Educational Research Journal, 52(1), 40-72. 